\title{
Workshop: Exploring participatory prototyping of services
}

\author{
Johan Blomkvist \\ Linköpings Universitet \\ johan.blomkvist@liu.se \\ Stefan Holmlid \\ Linköpings Universitet \\ stefan.holmlid@liu.se
}

\author{
Fredrik Sandberg \\ Linnaeus University \\ fredrik.sandberg@lnu.se
}

\author{
Bo Westerlund \\ Konstfack \\ bo.westerlund@konstfack.se
}

\begin{abstract}
This full day workshop intends to explore approaches, methods and techniques that can be used in participatory prototyping of services. The participants will contribute with their experiences of different ways of working with participatory prototyping. During the workshop the participants will share, explore and give feedback on the method or case that they present. By engaging in other methods there will also be a learning activity. Another aim of the workshop is to initiate research and development of knowledge within the emerging field of participatory prototyping of services and product service systems. One particular interest regards the relation between details and "the whole". The emphasis of the workshop is to have creative learning experiences.
\end{abstract}

\section{Author Keywords}

Participatory prototyping, participatory design, service design,

\section{ACM Classification Keywords \\ Design, Prototyping}

\section{BACKGROUND}

Prototyping is acknowledged as an important activity in participatory design, and participatory design is regarded as a good approach in order to create knowledge regarding desirable futures by a large amount of scholars. Christiane Floyd [7] describes prototypes as learning vehicles i.e. they support creating knowledge regarding the issue one is inquiring into.

Prototyping has long since been promoted as one of the key activities in designing successful systems and products and they are understood to be especially important when the design space is complex, since clients and other stakeholders might have a hard time understanding the future system being designed without the prototypes $[5,6,7,9]$. Tangibles, such as scenarios, visualisations, objects, etc. can be shared by stakeholders support exploration and understanding; as well as facilitate communication. Lawson [12] reasons that externalisation of designers' thoughts with the help of prototypes, etc. is one way to understand why this works well. Then the creation of knowledge can also be done in collaboration since these "external" artefacts are available for all participants.

\footnotetext{
Permission to make digital or hard copies of all or part of this work for personal or classroom use is granted without fee provided that copies are not made or distributed for profit or commercial advantage and that copies bear this notice and the full citation on the first page. To copy otherwise, or republish, to post on servers or to redistribute to lists, requires prior specific permission and/or a fee.

PDC'12, 12-AUG-2012, Roskilde, Denmark.

Copyright 2012 ACM ISBN 978-1-4503-0846-5/12/08 ..\$10.00.
}

Design of services is an emerging new territory for participation, which has been an issue at PDC and other conferences $[1,10,11,13]$. In order to achieve success there is need for better understanding of possible methods, techniques and approaches for participatory prototyping.

Service and product service systems are large fields that are rapidly transforming the society, business, and the way people use, consume and relate to many activities. Services are said to differ from the "traditional" view on products basically concerning temporality, ownership and access. These are important issues that might need to be inquired into with approaches and methods different from those usually used in participatory design [2].

Developments within companies seem to transform from being based on top-down development, to network based creation, which increases the demands on the prototyping activities. As one example, the use of design games [4] seems to be useful in transforming companies [14].

Product service systems, which can be complex assemblies, seem to be a promising perspective that can be used with the intention to enable a more sustainable lifestyle. One example of this emerging territory for exploration is collaborative consumption [3]. Many current examples of collaborative consumption and service networking are invented or developed by endusers, which is a major shift from "traditional" end-user involvement that often was initiated by companies already in the market. The complexity of and the rapid changes within the field provide a great challenge for the prototyping approaches, methods and tools. And also identify and include relevant stakeholders.

Although we have seen that the ambition in service design is to include different stakeholders, for some reasons it is not often feasible for practicing service designers to do so. One possible reason for this is unwillingness of client to pay for big collaborative approaches, and another is a lack of service specific prototyping techniques. Providing techniques that can support service development in practical ways in complex settings are needed to support the practice of service design.

Therefore it is important for the development of both the fields of service design and participatory design to gather a number of people to this workshop in order to share and create improved practical ways of conducting participatory design of services. It is also an opportunity to a deeper understanding of the challenges and opportunities, which can be subject to future research projects. 
In this workshop we are especially interested in how the prototyping activity can support both the understanding of details as well as "the whole" experience of the service or product service system. The prototyping can be staged in a number of different ways, e.g. in "the lab" or in situ, or involve one or several stakeholders.

\section{RELEVANCE FOR PARTICIPATORY DESIGN}

Service design is a new territory for design research in regard to scope and the "object" of design. The approach to service design is participatory and inter-disciplinary, contexts where prototyping is especially helpful. Participation in design of services does not only refer to the designer-user relationship, but also to different layers of service organizations and customer-customer relations.

\section{WORKSHOP FORMAT}

\section{Goals}

The overall goal is to co-produce knowledge on how services can be prototyped and understood, with a participatory design approach, as whole experiences as well as sequences of separate interactions between service provider(s), customer(s) and other stakeholders.

\section{Participants}

Participants are sought, researchers as well as practitioners, that have a range of experiences from different ways of working with participation, prototyping and service. Participants should be interested in the issue of including different stakeholders in the prototyping activity, and also be interested in exploring different methods that support zooming in and out on the service being designed. To ensure a good climate for discussions the desired number of participants will be between ten and twenty.

\section{How to participate, and before-the-workshop-blog}

If you are interested in participating in the workshop please submit a four-page position paper where you present a prototyping approach, method, technique or case study that you can share and explore.

The paper must be sent by e-mail no later than June 1st to fredrik.sandberg@lnu.se. We will respond on June 7th.

Participants will be invited to a blog where the workshop itself will be prototyped.

\section{Schedule}

The workshop extends over a full day, with this outline:

- Introduction to the workshop, the participants and approaches to service prototyping explored in previous research.

- Gallery presentations by participants of each approach, method, technique or case that was brought by participants.

- Active exploration in smaller groups of specific aspects and opportunities of the methods. One aspect that will be emphasised is how they support understanding of the relationship between the parts and the whole of the service, for designers and prototyping participants.

- Collect and document insights from the groups.

- $\quad$ Share experiences, and sum up

\section{After the workshop}

The organizers will create a summary of the learning from the workshop and present these on the blog and e.g. as an exhibit. Publication possibilities will be sought.

\section{The organizers of this workshop}

The people that organise and conduct the workshop are involved both in development of service design and participatory design.

\section{REFERENCES}

1. Andersen, Moll, and Mønsted. 2010. Prototyping (in) healthcare. In Proceedings of the 11th Participatory Design Conference. ACM, New York, NY, USA, 279-280.

2. Blomkvist, J. 2011. Conceptualising Prototypes in Service Design. Licentiate Thesis: Faculty of Arts and Sciences, No. 101. LiU-Tryck: Linköping, Sweden.

3. Botsman, R., and Rogers, R., (2011) What's mine is yours: how collaborative consumption is changing the way we live. London: Collins.

4. Brandt, E. (2006). Designing Exploratory Design Games: Proceedings of the 9th Participatory Design Conference 2006 (pp. 57-66). Trento, Italy: ACM.

5. Brandt, E., and Messeter, J,. 2004. Facilitating collaboration through design games. In Proceedings of the 8th conference on Participatory design, Vol. 1. ACM, New York, NY, USA, 121-131.

6. Buchenau and Suri (2000) Experience prototyping. In Proceedings of the 3rd conference on Designing interactive systems, ACM, NY, 424-433

7. Bødker, K., Kensing, F. and Simonsen, J.(2004) Participatory IT design: designing for business and workplace realities. MIT press, USA.

8. Floyd, Christiane (1984) A systematic look at prototyping, In R. Budde (ed.), Approaches to prototyping, Proceedings of the Working Conference on Prototyping, Namur, 1983 (Berlin: Springer), 1-18.

9. Greenbaum, J. and Kyng, M. (eds) (1991) Design at Work: Cooperative Design of Computer Systems. Lawrence Erlbaum Associates, New Jersey, USA.

10. Holmlid, S. (2009). Participative, co-operative, emancipatory: From participatory design to service design. 1st Nordic Conference on Service Design and Service Innovation, Oslo 2009.

11. Kimbell, L. (2009) Insights from service design practice, in proceedings 8th European Academy of Design, Aberdeen.

12. Lawson, Bryan (1997) How designers think: The design process demystified, 3rd ed. Oxford, UK: Architectural Press.

13. Sangiorgi, D. \& Clark, B. (2004) Toward a participatory design approach to service design, In Proceedings of the 8th conference on Participatory design, Vol. 1. ACM, NY, NY, USA,

14. Törpel, B., (2006). The Design Game in Participatory Design and Design Education - Chances, Risks and Side Effects. In Proceedings of the 9th Participatory Design Conference (57-66). Trento, Italy: ACM. 